\title{
VARIASI TEMPORAL DAN STABILITAS FISIK DAN KIMIA SENYAWA BIOAKTIF KAROTENOID RUMPUT LAUT COKLAT Turbinaria decurrens
}

\section{Temporal Variation and Physical and Chemical Stability of Carotenoids Bioactive Compounds from The Brown Algae Turbinaria decurrens}

\author{
Rini Susilowati ${ }^{1 *}$ dan Hedi Indra Januar ${ }^{1}$ \\ ${ }^{1}$ Balai Besar Penelitian dan Pengembangan Pengolahan Produk dan Bioteknologi Kelautan dan Perikanan, \\ JI. K.S. Tubun Petamburan VI, Jakarta Pusat, Indonesia \\ * Korespondensi Penulis: rinicas@yahoo.com
}

Diterima: 21 April 2014; Disetujui: 2 Juni 2014

\begin{abstract}
ABSTRAK
Pada pengembangan senyawa bioaktif karotenoid dari rumput laut coklat Turbinaria decurrens sebagai produk nutrasetikal atau pangan fungsional, pengetahuan mengenai variasi temporal dan stabilitas fisik dan kimia senyawa tersebut merupakan hal yang penting. Penelitian ini bertujuan untuk menjelaskan variasi temporal dan stabilitas fisik dan kimia senyawa karotenoid dari $T$. decurrens. Bahan baku T. decurrens diambil dari Pantai Binuangeun, Banten. Kuantifikasi kadar karotenoid pada sampel dilakukan terhadap ekstrak kasar etanol dari sampel dengan menggunakan teknik spektrofotometri UV-Vis. Variasi temporal kadar karotenoid dilakukan dengan pengambilan sampel pada musim penghujan (Februari), musim peralihan (April dan Oktober), serta musim kemarau (Juni dan Agustus), pada tahun 2012. Analisis variabel air (DO, pH, suhu, temperatur, salinitas, fosfat, dan nitrogen anorganik terlarut) dari titik pengambilan sampel juga dilakukan, untuk mengetahui faktor utama yang mempengaruhi produksi senyawa ini di alam. Analisis stabilitas senyawa dilakukan dengan perlakuan penambahan asam, basa, oksidator, dan suhu. Hasil pengujian menunjukan bahwa kadar karotenoid temporal dari alga ini berkisar 0,002-0,063 mg/g (bobot segar). Analisis korelasi terhadap variabel air menunjukkan bahwa kadar karotenoid dipengaruhi faktor musim, tidak tergantung pada variabel air lokal. Terkait dengan probabilitas fungsinya dalam fotosintesis, kadar tertinggi senyawa ini terdapat pada musim penghujan. Karotenoid dapat meluruh sebesar $84 \%$ pada perlakuan asam, $15 \%$ pada perlakukan basa, $28 \%$ pada perlakukan oksidasi, dan $15 \%$ pada suhu tinggi $\left(70^{\circ} \mathrm{C}\right)$. Dengan demikian, pada pengembangannya sebagai produk pangan fungsional atau nutrasetikal, diperlukan teknik mikroenkapsulasi untuk menjaga stabilitas fisik dan kimia senyawa karotenoid T. decurrens.
\end{abstract}

KATA KUNCl: $\quad$ karatenoid, Turbinaria decurrens, variasi temporal, stabilitas fisik dan kimia

\section{ABSTRACT}

On the development of carotenoids bioactive compounds from brown seaweed Turbinaria decurrens as nutraceuticals or functional food products, the temporal content variation and the physical and chemical stability of its compound are important to know. This study aimed to explain the temporal content variation and its physical and chemical stability of carotenoid from $T$. decurrens. The raw material was taken from Binuangeun Beach, Banten. Quantification of carotenoids content in the sample was performed on the crude ethanol extract of the sample using UV-Vis spectrophotometry techniques. Temporal variation of carotenoid content was measured on the sample taken in the rainy season (February), transitional season (April and October), and the dry season (June and August), in the year of 2012. Water analysis (DO, pH, temperature, salinity, phosphate, and dissolved inorganic nitrogen) from the point of sampling were conducted to determine the main factors affecting the production of these compounds naturally. The compound stability analysis was done by treating the extract with acid, base, oxidator and temperatures. The results showed that temporal carotenoid content of $T$. decurrens ranged from 0.002 to $0.063 \mathrm{mg} / \mathrm{g}$ (fresh weight). Correlation analysis on the water parameters showed that carotenoid content were influenced by seasonal factors, and not dependent on local water variables. Related to functional probability in photosynthesis, the highest content of these compounds were in the rainy season. The carotenoid could decayed by $84 \%$ in the acid treatment, $15 \%$ in alkaline treatment, $28 \%$ in the oxidation treatment, and $15 \%$ at high temperature $\left(70^{\circ} \mathrm{C}\right)$. Therefore, for further development as a functional food or nutraceutical, the microencapsulation techniques should be applied to maintain physical and chemical stability.

KEYWORDS: carotenoid, Turbinaria decurrens, temporal variation, physical and chemical stability 


\section{PENDAHULUAN}

Selain berguna sebagai produk pangan, rumput laut juga merupakan bahan alami yang berpotensi dikembangkan untuk nutrasetikal atau pangan fungsional. Hal ini karena rumput laut mengandung senyawa aktif yang berguna sebagai antioksidan, antiinflamasi, antikanker dan lain sebagainya ( $\mathrm{Heo}$ et al., 2005; Chandini et al., 2008; Ganesan et al., 2008). Salah satu spesies rumput laut yang potensial adalah Turbinaria decurrens yang banyak ditemukan di perairan pesisir Indonesia, seperti Pantai Binuangeun, Provinsi Banten. Turbinaria decurrens diketahui mengandung senyawa karotenoid, terutama fukosantin, yang memiliki aktivitas antioksidan, antiinflamasi, antikoagulan, antivirus dan antitumor (Yan et al., 1999; Sachindra et al., 2007; Gupta \& Abu-Ghannam, 2011; Kelman et al., 2012). Hasil pengujian toksisitas akut secara in vivo menunjukkan bahwa ekstrak $T$. decurrens relatif aman untuk dikembangkan sebagai bahan nutrasetikal (Wikanta et al., 2011).

Pada pengembangan karotenoid sebagai bahan baku untuk produk nutrasetikal atau pangan fungsional, informasi mengenai variasi kadar temporal dan sifat stabilitasnya adalah hal yang mendasar untuk diketahui. Sebagai senyawa yang termasuk dalam kelompok pigmen, dapat diduga terdapat variasi temporal kadar yang terkait dengan kondisi lingkungan, seperti kondisi nutrien, suhu air laut, dan lainnya. Pengetahuan mengenai variasi ini merupakan salah satu faktor penting dalam standarisasi bahan baku yang bersumber dari bahan alam, besaran deviasi dalam keseragaman mutu dan khasiatnya (Khalid et al., 2011). Selain itu, pengetahuan akan sifat stabilitas fisika dan kimia suatu bahan aktif akan menjadi baseline pada proses formulasi bahan tersebut, untuk mempertahankan kestabilan dan sifat bioaktivitasnya. Hal ini merupakan dasar dilaksanakannya penelitian ini. Riset bertujuan untuk menjelaskan karakteristik kuantitas dan stabilitas fisika dan kimia senyawa karotenoid dalam ekstrak T. decurrens pada variasi temporal selama satu tahun yang meliputi musim penghujan, peralihan, dan musim kemarau. Hasil dari penelitian akan berguna sebagai baseline data untuk pengembangan rumput laut ini sebagai produk pangan fungsional maupun produk nutrasetikal.

\section{BAHAN DAN METODE}

\section{Pengambilan Sampel T. decurrens}

Sampel T. decurrens diambil di Pantai Binuangeun - Banten pada kurun waktu sepanjang tahun 2012.
Pengamatan terhadap variasi kadar temporal senyawa karotenoid dilakukan pada sampel yang diambil sebanyak lima kali dalam setahun, yaitu pada musim penghujan (Februari), musim peralihan (April dan Oktober), serta musim kemarau ( Juni dan Agustus). Sampel T. decurrens diambil pada saat kondisi pasang surut selama dua hari pada tiga stasiun (Gambar 1), yakni Kembang Karang (A) $\left(6^{\circ} 50^{\prime} 36.80^{\prime \prime}\right.$ LS; $\left.105^{\circ} 53^{\prime} 24.17 " \mathrm{BT}\right)$, Karang Anyar (B) (6 $6^{\circ} 50^{\prime} 32.22$ " LS; $105^{\circ} 53^{\prime} 38.07^{\prime \prime}$ BT), dan Panto (C) (6 $6^{\circ} 50^{\prime} 25.38^{\prime \prime}$ LS; $\left.105^{\circ} 54^{\prime} 8.88^{\prime \prime} \mathrm{BT}\right)$.

\section{Pengamatan Kualitas Air di Lokasi Pengambilan $T$. decurrens}

Pada tiap titik pengambilan sampel, dilakukan pengamatan kualitas air, meliputi dissolved inorganic nitrogen (DIN; nitrogen anorganik terlarut sebagai penjumlahan dari nitrat, nitrit, dan amonia) dan fosfat yang diukur in situ menggunakan colorimeter $\mathrm{HACH}$ DR-890. Sementara pengamatan dissolved oxygen (DO), $\mathrm{pH}$, suhu, dan salinitas menggunakan perangkat $\mathrm{HACH}$ handled dan dilakukan secara langsung (in situ). Seluruh variabel yang dianalisis dilakukan dengan tiga kali ulangan.

\section{Ekstraksi Karotenoid dalam T. decurrens}

Proses ekstraksi untuk preservasi dilakukan langsung di lapangan. Limapuluh gram sampel $T$. decurrens diekstraksi dengan menggunakan $100 \mathrm{ml}$ etanol (PA Grade) menggunakan botol gelap. Setiap sampel dibuat tiga ulangan, kemudian disimpan dalam coolbox berisi es dan dibawa ke laboratorium di Jakarta. Di laboratorium, sampel selanjutnya diekstraksi ulang dengan menggunakan $2 \times 100 \mathrm{ml}$ pelarut yang sama. Ekstrak yang dihasilkan kemudian diambil $5 \mathrm{ml}$ dan diukur kadar karotenoidnya untuk pengamatan variasi temporal kadar karotenoid, sedangkan sisanya diambil $50 \mathrm{ml}$, dipekatkan dan dikeringbekukan untuk keperluan analisis stabilitas.

\section{Analisis Stabilitas Fisika dan Kimia Senyawa Karotenoid $T$. decurrens}

Analisis stabilitas fisika dan kimia senyawa karotenoid $T$. decurrens dilakukan berdasarkan metode Musmade et al. (2011). Stabilitas fisika diuji dengan memberikan perlakuan suhu $\left(30-70{ }^{\circ} \mathrm{C}\right)$, sedangkan stabilitas kimia ditentukan dengan memberikan perlakuan asam, basa dan oksidator pada ekstrak $T$. decurrens, kemudian diuji kadar karotenoidnya. Masing-masing perlakuan ini dijabarkan sebagai berikut:

\section{Pengaruh asam, basa, dan oksidasi}

Sepuluh miligram ekstrak kering dimasukkan ke dalam 9 botol vial gelap. Perlakuan asam dilakukan 

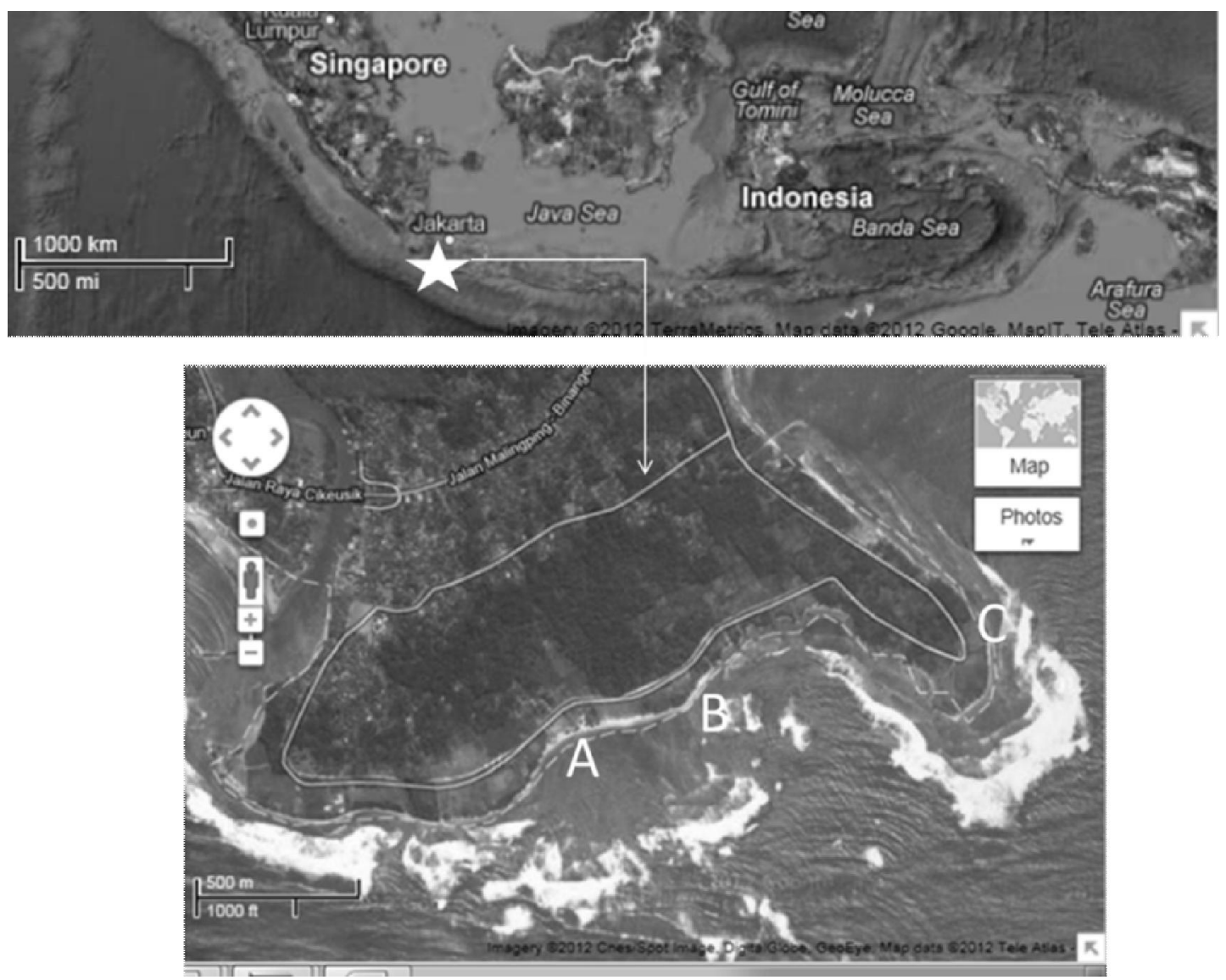

Gambar 1. Lokasi sampling di pantai Binuangeun - Banten, Indonesia, Kembang Karang (A), Karang Anyar (B), dan Panto (C) (sumber Google Map, 2012)

Figure 1. Sampling location in Binuangeun Beach - Banten, Indonesia, Kembang Karang (A), Karang Anyar (B), and Panto (C) (Google Map, 2012)

dengan melarutkan $10 \mathrm{mg}$ ekstrak dalam $10 \mathrm{ml}$ $0,1 \mathrm{~N} \mathrm{HCl}$ dalam etanol. Perlakuan basa dilakukan dengan melarutkan $10 \mathrm{mg}$ ekstrak dalam $10 \mathrm{ml}$ $0,1 \mathrm{~N} \mathrm{NaOH}$ dalam etanol. Sementara perlakuan oksidasi dilakukan dengan melarutkan ekstrak dalam $10 \mathrm{ml}$ hidrogen peroksida $3 \%$ dalam etanol. Keseluruhan larutan kemudian disimpan selama 8 jam di ruangan gelap pada suhu rendah. Ketiga perlakuan ini dibuat dalam tiga ulangan.

\section{Pengaruh suhu}

Sepuluh miligram ekstrak kering dipanaskan pada suhu 50,60 , dan $70{ }^{\circ} \mathrm{C}$ selama
3 jam, kemudian ekstrak dilarutkan dalam $10 \mathrm{ml}$ etanol.

\section{Kuantifikasi Kadar Karotenoid}

Kuantifikasi kadar karotenoid dari setiap sampel dilakukan menggunakan spektrofotometri UV-Vis Shimadzu Lamda-25. Pada tahapan awal, setiap sampel diukur intensitas serapannya pada tiga panjang gelombang, yaitu 470, 648, dan $664 \mathrm{~nm}$. Data absorbansi dari ketiga panjang gelombang tersebut dimasukkan ke dalam rumus perhitungan kadar karotenoid dalam etanol Lichtenthaler dan Buschmann (2001) berikut:

$$
\begin{gathered}
{[\text { Karotenoid }]=\frac{[1000 a-1,63(13,36 c-5,19 b)-104,96(27,43 b-8.12 c)]}{221}} \\
\\
a=\text { Absorbansi pada } 470 \mathrm{~nm} \\
b=\text { Absorbansi pada } 648 \mathrm{~nm} \\
c=\text { Absorbansi pada } 664 \mathrm{~nm}
\end{gathered}
$$




\section{HASIL DAN PEMBAHASAN}

\section{Variasi Temporal Kandungan Karotenoid}

Hasil pengamatan kualitas air dari ketiga titik pengambilan sampel disajikan pada Gambar 2. Hasil pengukuran $\mathrm{DO}, \mathrm{pH}$, salinitas, dan temperatur memperlihatkan nilai normal. Namun, fosfat dan nitrogen (rataan 0,3 dan $0,16 \mathrm{ppm}$ ) memiliki nilai di atas ambang batas normal, yaitu 0,011 dan 0,007 ppm (Priyanto, 2011). Uji Kruskall Wallis menemukan bahwa variabel air berbeda secara signifikan berdasarkan periode pengambilan contoh.

Sementara $T$. decurrens yang diambil dari tiga stasiun di Pantai Binuangen mengandung karotenoid pada kisaran 0,002-0,063 mg/g FW (fresh weight/ bobot segar). Kadar karotenoid total ditunjukkan pada Gambar 3.

Analisis statistik Kruskall-Walls menunjukkan bahwa kandungan karotenoid total hanya berbeda berdasarkan periode pengambilan contoh $(P<0,05)$. Jumlah karotenoid dari contoh yang diambil pada pagi hari tidak berbeda dengan contoh yang diambil pada sore hari $(P=0,758)$. Hasil yang sama juga ditunjukkan pada contoh yang diambil di tiga lokasi berbeda $(P=0,803)$.
Selaras dengan analisis variabel air, kadar karotenoid hanya berbeda secara signifikan berdasarkan periode pengambilan contoh. Analisis korelasi Spearman menunjukkan bahwa karotenoid total hanya memiliki korelasi kuat yang signifikan dengan suhu permukaan air laut $(R=0,682$ pada $\mathrm{P}<0,05)$. Tidak ada perbedaan yang signifikan antara setiap kali pengambilan contoh dalam sehari (pagi dan sore) serta lokasi pengambilan contoh. Hal ini mengindikasikan bahwa perubahan karotenoid total pada rumput laut itu tidak disebabkan oleh faktor lokal, melainkan faktor musiman. Faktor suhu ini secara gradual mengalami perubahan menurut musim sedangkan $\mathrm{DO}, \mathrm{pH}$, dan nutrisi tidak secara signifikan mempengaruhi kandungan karotenoid.

Fluktuasi musiman kandungan pigmen pada rumput laut dilaporkan oleh beberapa peneliti (Zavodnik, 1973; Ragan \& Jensen 1978; Rosenberg et al., 1982; Flores Moya et al., 1995; Banerjee et al., 2009). Perubahan musiman kandungan pigmen pada rumput laut berhubungan dengan tingkat nutrien di perairan (Aguilera et al., 2002). Pada studi ini, tingkat nutrien terdeteksi pada status eutrofik, kondisi di mana perairan sangat subur dan sangat cocok untuk pertumbuhan rumput laut. Meskipun demikian, tidak ada hubungan yang kuat antara tingkat nutrien di
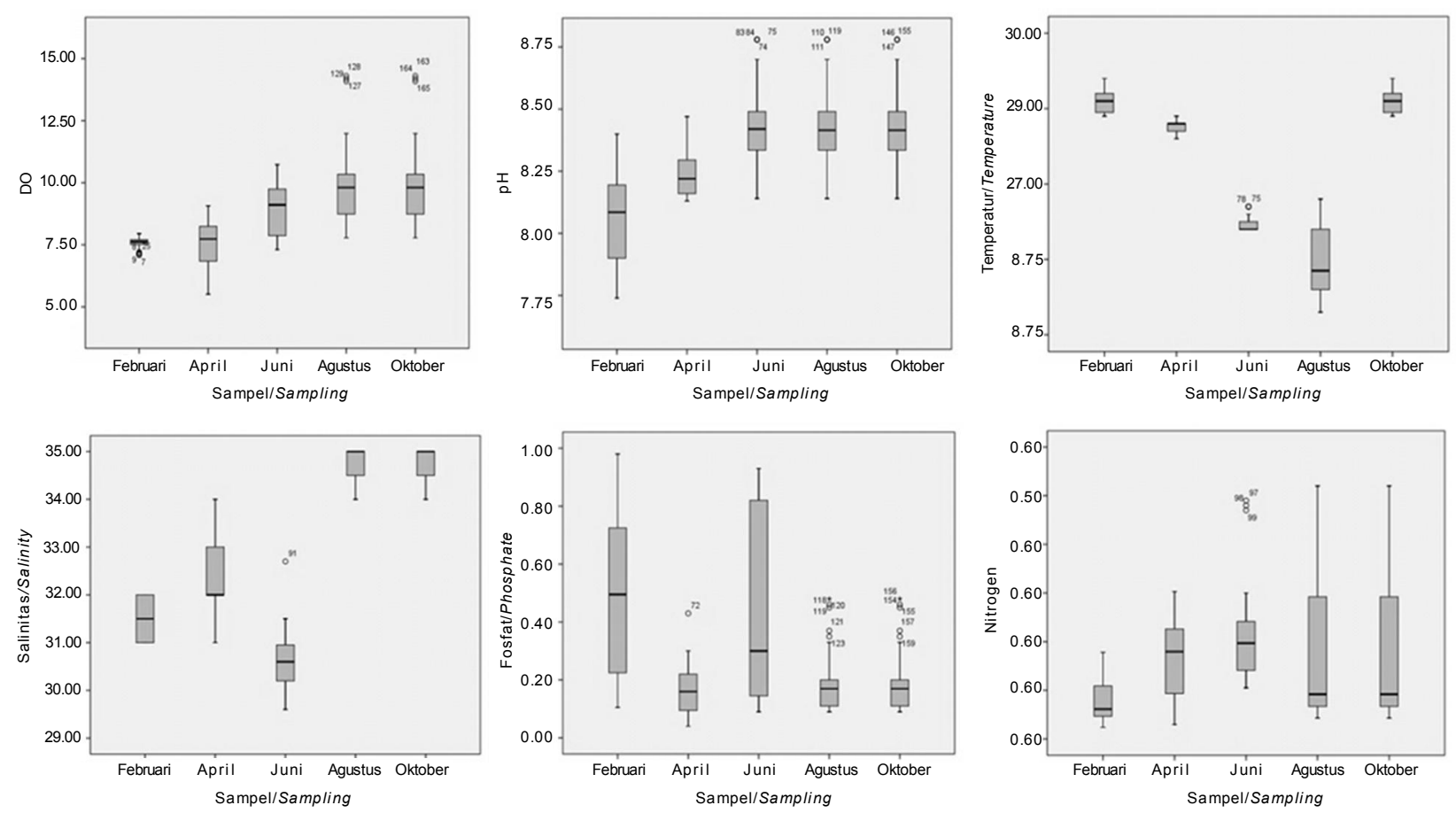

Gambar 2. Grafik Boxplot variabel air (DO, pH, suhu, temperatur, salinitas, fosfat, dan nitrogen anorganik terlarut) pada saat pengambilan sampel $T$. decurrens di Pantai Binuangeun Banten.

Figure 2. Boxplot Graph of water variables (DO, pH, Temperature, Salinity, Phosphate, and Dissolved Inorganic Nitrogen) at the time of T. decurrens sampling at Binuangeun-Banten Beach. 
A

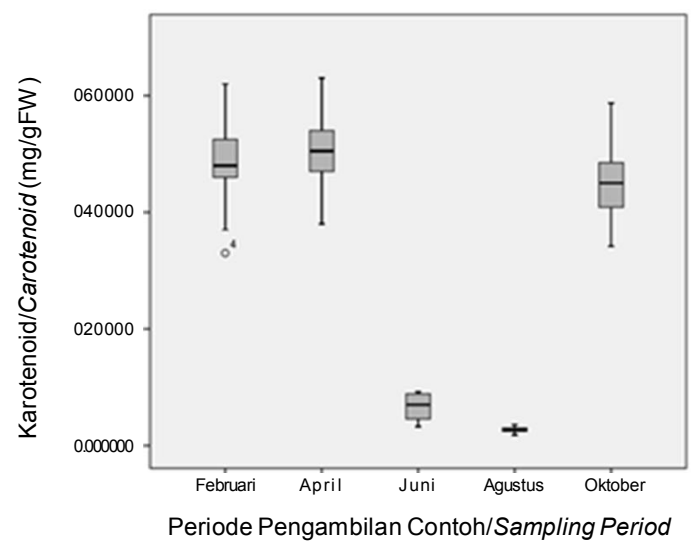

B

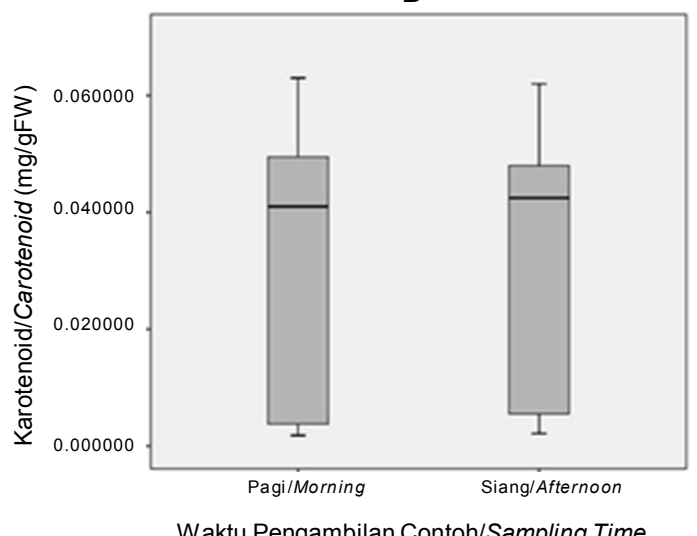

C

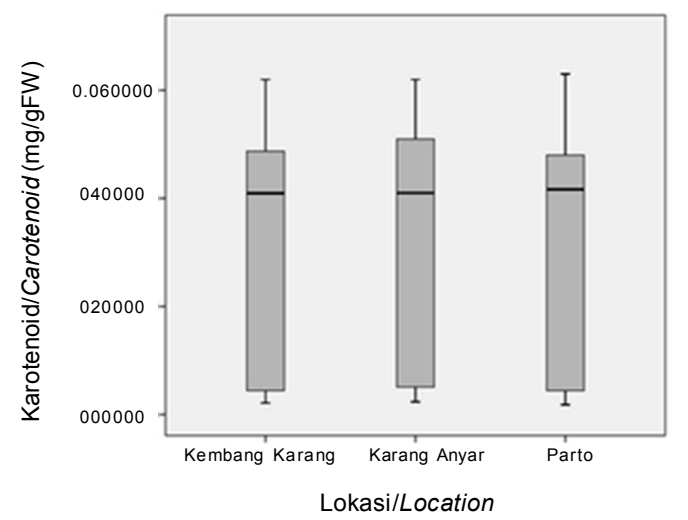

Gambar 3. Boxplot rendemen karotenoid T. decurrens dari pengambilan contoh pada waktu dan lokasi yang berbeda. (A) periode pengambilan contoh (B) waktu pengambilan contoh (C) lokasi pengambilan contoh.

Figure 3. Boxplot of carotenoid rendement of T. decurrens from different time and location sampling. (A) sampling period $(B)$ sampling time $(C)$ location sampling.

perairan dengan kandungan karotenoid pada rumput laut. Oleh karena itu, tingkat nutrien diduga tidak menjadi penyebab fluktuasi karotenoid pada rumput laut di perairan ini.

Pada sisi yang lain, telah terdeteksi jumlah karoten dan $\alpha$-tokoferol dari rumput laut coklat hasil budidaya di Teluk Tanggal-Hokkaido, Jepang pada periode bulan-bulan hangat (Honya et al., 1994). Perubahan musiman radiasi UVB sinar matahari diperkirakan memberi dampak yang signifikan pada kandungan pigmen rumput laut (Altamirano et al., 2000). Fakta tersebut diperkuat dengan tingginya senyawa antioksidan pada ganggang merah yang diamati ketika tingkat radiasi dan suhu berada pada level yang tinggi (Glibert et al., 1995; Sampath-Wiley et al., 2008). Namun hampir tidak ada bukti bahwa radiasi UV meningkat dalam waktu yang sama dengan tingginya suhu permukaan laut (SPL) di daerah Binuangeun. Meskipun SPL meningkat secara harian pada saat penelitian, namun massa air hangat tidak terjadi pada waktu yang sama dengan musim kemarau di Indonesia. Pola SPL di wilayah barat
Indonesia tinggi pada awal tahun, turun sekitar JuniSeptember, dan naik kembali pada akhir tahun (NOAA, 2012). Berdasarkan hal tersebut, SPL meningkat bersamaan dengan musim penghujan Indonesia. Menurut Moron et al. (2010), musim di Indonesia memiliki karakteristik iklim muson dengan musim penghujan lebat pada Desember-JanuariFebruari (DJF), dan musim kemarau pada bulan JuniJuli-Agustus (JJA). Hal ini memberikan gambaran mengenai faktor temporal pada variasi kandungan karotenoid dalam $T$. decurrens yang ditemukan dalam penelitian ini. Hal yang sama terjadi pula pada spesies rumput laut yang berbeda di mana produksi pigmen lebih tinggi selama musim penghujan (Godínez-Ortega et al., 2008).

Fluktuasi konsentrasi pigmen dapat meningkatkan kapasitas fotosintesis atau sebagai agen antiradikal untuk menghindari kerusakan saat fotosintesis terjadi (Denault et al., 2000; Sigaud-Kutner et al., 2002; Pinto et al., 2003). Oleh karena itu, fluktuasi konsentrasi karotenoid yang teramati dalam penelitian ini adalah diduga sebagai respon rumput laut untuk 


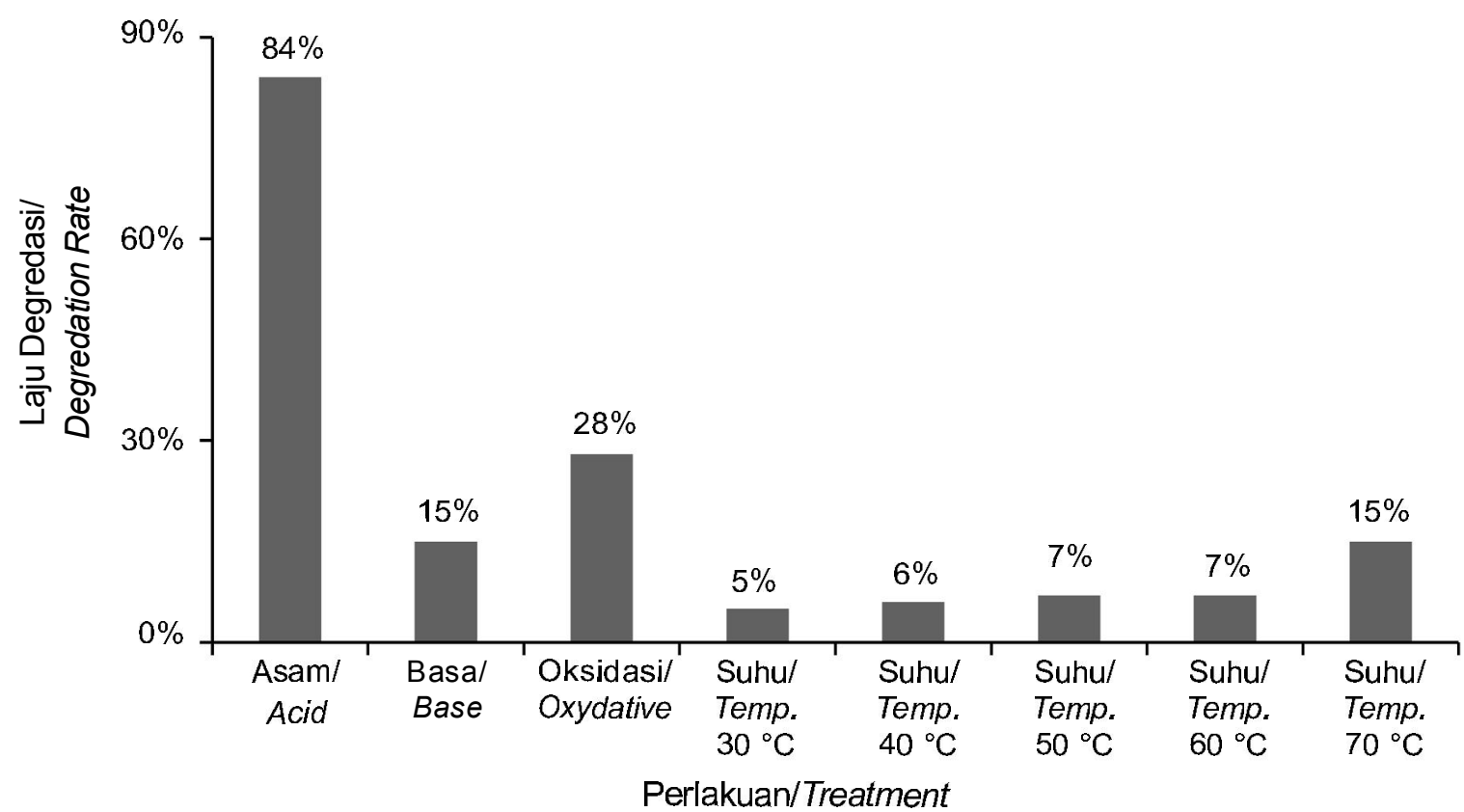

Gambar 4. Pengaruh variabel kimia (asam, basa, dan oksidasi) dan fisik (panas) terhadap stabilitas senyawa bioaktif karotenoid pada T. decurrens.

Figure 4. Effect of chemicals (acid, base and oxidator) and physical variables (temperature) on the stability of carotenoid bioactive compounds of T. decurrens.

meningkatkan kapasitas fotosintesis selama musim penghujan. Alga merah Gracilaria domingensis dari populasi alami di Pantai Rio Grande do Norte, Brasil juga memiliki respon yang sama untuk memaksimalkan tingkat fotosintesisnya pada musim penghujan (Pereira et al., 2012).

\section{Stabilitas Senyawa Bioaktif Karotenoid}

Stabilitas senyawa bioaktif diperlukan untuk pengembangan nutrasetikal. Informasi mengenai hal tersebut dijadikan dasar dalam memformulasi produk yang menggunakan bahan baku rumput laut. Hasil pengujian diperlihatkan pada Gambar 4 .

Secara umum, golongan senyawa bioaktif pada T. decurrens rentan terhadap induksi stres kimiawi maupun fisik. Penurunan kadar karotenoid akibat pengaruh kimia ini diduga berkaitan erat dengan banyaknya ikatan rangkap pada senyawa karotenoid. Karotenoid pada bahan pangan merupakan senyawa tetraterpenoid dengan jumlah atom karbon 40 yang terdiri atas 8 unit isoprenoid C5 (IP5). Ikatan rangkap pada kerangka dasar senyawa karotenoid sangat berperan terhadap warna yang diekspresikan. Warna karotenoid semakin kuat dengan semakin banyaknya ikatan rangkap. Paling tidak dibutuhkan 7 ikatan rangkap dalam karotenoid untuk bisa menghasilkan warna. Sementara itu ikatan rangkap di bagian tengah kerangka karotenoid sangat peka terhadap oksidator (Anon., 2012).
Karotenoid yang dimiliki oleh $T$. decurrens sangat reaktif terhadap asam dibandingkan terhadap basa. Sementara efek pada senyawa oksidatif dapat terjadi karena sifat antioksidan dari senyawa karotenoid yang dimiliki oleh organisme tersebut. Penurunan kadar karotenoid akibat pengaruh kimia ini diduga berkaitan erat dengan banyaknya ikatan rangkap pada senyawa karotenoid. Karotenoid pada bahan pangan merupakan senyawa tetraterpenoid dengan jumlah atom karbon 40 yang terdiri atas 8 unit isoprenoid $\mathrm{C}_{5}\left(\mathrm{IP}_{5}\right)$. Ikatan rangkap pada kerangka dasar senyawa karotenoid sangat berperan terhadap warna yang diekspresikan. Warna karotenoid semakin kuat dengan semakin banyaknya ikatan rangkap. Paling tidak dibutuhkan 7 ikatan rangkap dalam karotenoid untuk bisa menghasilkan warna. Sementara itu ikatan rangkap di bagian tengah kerangka karotenoid sangat peka terhadap oksidator (Anon., 2012).

Selain itu, pengaruh panas menunjukkan laju degradasi kandungan karotenoid sebesar $15 \%$ pada suhu $70^{\circ} \mathrm{C}$ selama $3 \mathrm{jam}$. Pada penelitian sebelumnya yang dilakukan oleh Musmade et al. (2011), pemanasan bubuk obat pada suhu $55^{\circ} \mathrm{C}$ minimal selama 3 jam telah menunjukkan degradasi senyawa bioaktif yang signifikan. Menurut Wahyuni dan Widjanarko (2014), karotenoid belum mengalami dekomposisi pada pemanasan sampai dengan suhu $60^{\circ} \mathrm{C}$, tetapi stereoisomernya mengalami perubahan. Mereka menemukan bahwa pemanasan pada suhu 
$100^{\circ} \mathrm{C}$ selama 5 jam menghasilkan retensi senyawa karotenoid labu kuning mencapai nilai terendah, sebesar $68,64 \%$. Pada pemanasan suhu tinggi senyawa karotenoid berubah menjadi senyawa ion berupa keton yang disebabkan oleh adanya sejumlah ikatan rangkap dalam struktur molekulnya (Histifarina \& Musaddad, 2004). Di samping itu, peningkatan suhu menyebabkan perpindahan massa air hingga mencapai kesetimbangan yang sama dengan lingkungannya (Miranda et al., 2009). Hal ini ditemui pada rumput laut jenis Himanthalia elongata yang mencapai kesetimbangan massa air setelah dipanaskan pada suhu $25^{\circ} \mathrm{C}$ selama 8 jam dan pada kondisi ini pula menyebabkan degradasi senyawa bioaktif (phytochemical) terutama pada kandungan total flavonoid dan total penol masing-masing sebesar 49 dan $51 \%$ bila dibandingkan pada kondisi segar (Gupta \& Abu-Ghannam, 2011).

\section{KESIMPULAN}

Seiring waktu $T$. decurrens akan memproduksi senyawa karotenoid secara fluktuatif dan mencapai puncak produksinya saat musim penghujan, untuk meningkatkan kapasitas fotosintesisnya. Oleh karena itu, pada pengembangan karotenoid sebagai bahan baku produk pangan fungsional, panen rumput laut ini akan sangat baik dilakukan pada sekitar musim penghujan dan peralihan. Senyawa ini memiliki tingkat stabilitas rendah, maka pada proses formulasinya menjadi produk akhir juga harus dilakukan dengan teknik yang dapat mempertahankan stabilitas, seperti penggunaan teknik mikroenkapsulasi. Kedua informasi karakteristik senyawa bioaktif ini dapat dipergunakan sebagai faktor yang penting pada pengembangan karotenoid rumput laut untuk produk nutrasetikal.

\section{UCAPAN TERIMA KASIH}

Penelitian ini dibiayai oleh Balai Besar Penelitian dan Pengembangan Pengolahan Produk dan Bioteknologi Kelautan dan Perikanan (BBP4B-KP). Ucapan terima kasih disampaikan pada Umar Setiana dan Aceng yang membantu dalam penanganan dan preservasi sampel di lapangan. Selain itu ucapan terima kasih juga disampaikan pada Nanik Dolaria, Helena Manik, dan Sri Iswani, di BBP4B-KP, yang membantu dalam pelaksanaan ekstraksi dan analisis variabel air.

\section{DAFTAR PUSTAKA}

Aguilera, J., Bischof, K., Karsten, U., Hanelt, D., \& Wiencke, C. (2002). Seasonal variation in ecophysicological patterns in macroalgae from the
Artic Ffjord. II. Pigment accumulation and biochemical defence systems against high light stress. Marine Biology, 140(6): 1087-1095.

Altamirano, M., Flores-Moya, A., Conde F, \& Figueroa, F.L. (2000). Growth seasonality, photosynthetic pigments, and carbon and nitrogen content in relation to environmental factors: a field study of Ulva olivascens (Ulvales, Chlorophyta). Phycologia. 39(1): 50-58.

Anonim. (2012). Pewarna alami untuk pangan : Kuningmerah karotenoid. Seafast Centre. http:// seafast.ipb.ac.id/tpc-project/wp-content/uploads/ 2013/03/10-kuning-merah-karotenoid.pdf

Banerjee, K., Ghosh, R., Homechaudhuri, S., and Mitra A. (2009). Seasonal variation in the biochemical composition of red seaweed (Catenella repens) from Gangetic Delta, Northeast Coast of India. J. Earth Syst. Sci. 118(5): 497-505.

Chandini SK, Ganesan, P., \& Bhaskar N. 2008. In vitro antioxidant activities of three selected brown seaweeds of India. Food. Chemistry, 107(2): 707713.

Denault, M., Stieve, E., \& Valiela I. 2000. Effect of Nitrogen Load and Irradiance on Photosynthetic Pigment Concentration in Cladophora vagabunda and Gracilaria tivahiae in Estuaries of Waquoit Bay. Biology Bulletin, 199(2): 223-225.

Flores Moya, A., Fernández, J.A., \& Niell, F.X. (1995). Seasonal variations of photosynthesis in Phyllariopsis purpurascens (Phaeophyta) from the Strait of Gilbaltar J. Phycol. 31(6): 867-874.

Ganesan, P., Kumar, C.S., \& Bhaskar, N. (2008). Antioxidant properties of methanol extract and its solvent fractions obtained from selected Indian red seaweeds. Bioresour. Tech. 99(8): 2717-2723.

Glibert, P.M., Conley, D.J., Fisher, T.R., Harding, LJ. Jr, \& Malone, T.C. (1995). Dynamic of the 1990 winter/ spring bloom in Chesapeake Bay. Mar. Ecol. Prog. Ser. 122(1): 27-43.

Godínez-Ortega, J.L., Snoeijs, P., Robledo, D., FreilePelegrín, Y., \& Pedersén, M. (2008). Growth and pigment composition in the red alga Halymenia floresii cultured under different light qualities. J. App. Phycol. 20(3): 253-260.

Gupta, S. \& Abu-Ghannam, N. (2011). Recent developments in the application of seaweeds or seaweed extracts as a means for enhancing the safety and quality attributes of foods. Innovative Food Science and Emerging Technologies (12): 600-609

Heo, S.J., Park, E.J., Lee, K.W., \& Jeon Y.J. 2005. Antioxidant activities of enzymatic extracts from brown seaweeds. Bioresour. Tech. 96(14): 1613-1623.

Histifarina, D. \& Musaddad, D. (2004). Penggunaan sulfit dan kemasan vakum untuk mempertahankan mutu tepung bawang merah selama penyimpanan. Jurnal Hortikultura. 14(1): 67-73

Honya, M., Kinoshita, T., Ishikawa, M., Mori, H., \& Nisizawa, K. (1994). Seasonal variation in the lipid content of cultured Laminaria japonica: fatty acids, sterols, 3-carotene, and tocopherol. J. App. Phycol. 6(1): 25-29. 
Kelman D., Posner E.K., Mcdermid K.J., Tabandera N.K., Wright PR, \& Wright AD. (2012). Antioxidant activity of hawaiian marine algae. Marine Drugs. 10(2): 403416.

Khalid H, Zhari I, Amirin S., \& Pazilah, I. (2011). Accelerated stability and chemical kinetics of ethanol extracts of fruit of Piper sarmentosum using high performance liquid chromatography. Iranian J. Pharm. Res. 10(3): 403-413.

Lichtenthaler, H.K. \& Buschmann, C. (2001). Chlorophylls and Carotenoids: Measurement and Characterization by UV-VIS Spectroscopy. In Wrolstad, R.E. (eds.). Current Protocols in Food Analytical Chemistry. John Wiley \& Sons, Inc.

Miranda M, Maureira H, Rodríguez K, \& Vega-Gálvez A. (2009). Influence of temperature on the drying kinetics, physicochemical properties, and antioxidant capacity of Aloe Vera (Aloe Barbadensis Miller) gel. Journal of Food Engineering, 91: 297-304.

Moron, V., Robetson, A.W., \& Qian, J.H. (2010). Local versus regional-scale characteristics of monsoon onset and post-onset rainfall over Indonesia. Clim. Dyn. 34(2): 281-299.

Musmade, P., Vadera, N., \& Subramanian, G. (2011). Stability-indicating HPTLC determination of imatinib mesylate in bulk drug and pharmaceutical dosage. In Srivastava MM. (eds.). HPTLC: High-Performance Thin-Layer Chromatography. Springer-Verlag, Berlin Heidelberg. p. 93-104.

NOAA. (2012). www.noaa.gov. Di akes pada tanggal 18 Mei 2014.

Pereira, D.C., Trigueiro, T.G., Colepicolo, P., and MarinhoSoriano, E. (2012). Seasonal changes in the pigment composition of natural population of Gracilaria domingensis (Gracilariales, Rhodophyta). Rev. Brasileira de Farmacognosia. 22(4): 874-880.

Pinto, E., Nieuwerburgh, L.V., Barros, M.P., Pedersén, M., Colepicolo, P., \& Snoeijs, P. (2003). Densitydependent patterns of thiamine and pigments in production in Nitzschia microcephala. Phytochem. 63(2): 155-163.

Priyanto, H.B. (2011). Trophic level of Jakarta Bay waters and potential occurence of harmful algal blooms (HABs). Indonesian. Oceanol. Limnol. 37(2): 247262.
Ragan, M.A. \& Jensen, A. (1978). Quantitative studies on brown algal phenols. II. Seasonal variation in polyphenol content of Ascophyllum nodosum and Fucus vesiculosus. J. Exp. Mar. Biol. Ecol. 34(3): 245258.

Rosenberg, G. \& Ramus, J. (1982). Ecological growth strategies in the seaweeds Gracilaria foliifera (Rhodophyceae) and Ulva sp. (Chlorophyceae): photosynthesis and antenna composition. Mar. Ecol. Prog. Ser. 8(3): 233-241.

Sachindra, N.M., Sato, E., Maeda, H., Hosokawa, M., Niwano, Y., Kohno, M., \& Miyashita, K. (2007). Radical scavenging and singlet oxygen quenching activity of marine carotenoid fucoxanthin and its metabolites. J. Agricult. Food. Chem. 55(21): 8516-8522.

Sampath-Wiley, P., Neefus, C.D., \& Jahnke, L.S. (2008). Seasonal effects of sun exposure and emersion on intertidal seaweed physiology: fluctuations in antioxidant contents, photosynthetic pigments and photosynthetic efficiency in the red alga Porphyra umbilicalis Kützing (Rhodophyta, Bangiales). J. Exp. Mar. Biol. Ecol. 361(2): 83-91.

Sigaud-Kutner, T.C.S, Pinto, E., Okamoto, O.K., Latorre, L.R., \& Colepicolo, P. (2002). Changes in superoxide dismutase activity and photosynthetic pigment content during growth of marine phytoplankters in batch-cultures. Physiol. Plantarum. 114(4): 566-572.

Wahyuni, D.T. \& Widjanarko, S.B. (2014). Pengaruh Jenis pelarut dan lama ekstraksi terhadap ekstrak karotenoid labu kuning dengan metode gelombang ultrasonik. Jurnal Pangan dan Agroindustri. 3(2): 390401

Wikanta, T., Resty, P., Lestari, R., \& Nurrahmi D.F. (2011). Pengaruh pemberian ekstrak etanol Turbinaria decurrens terhadap perbaikan kerusakan hati tikus putih. Jurnal Pasca Panen.

Yan, X, Chuda, Y, Suzuki, M., \& Nagata, T. (1999). Fucoxanthin as the major antioxidant in Hijikia fusiformis, a common edible seaweed. Biosci. Biotechol. Biochem. 63(3): 605-607.

Zavodnik, N. (1973). Seasonal variations in rate of photosynthetic activity and chemical composition of the littoral seaweeds common to north adriatic. Part II. Wrangelia penicillata C.AG. Botanica Marina. 16(3): 166-170. 